\title{
Effect of long term fertilization on phosphorus dynamics in root zone environment under finger millet - Maize cropping sequence
}

\author{
Kalaiselvi, $\mathrm{K}$. \\ Department of Soil Science \& Agricultural Chemistry, Tamil Nadu Agricultural University, \\ Coimbatore - 641003 (Tamil Nadu), India \\ D. Jayanthi \\ Department of Soil Science \& Agricultural Chemistry, Tamil Nadu Agricultural University, \\ Coimbatore - 641003 (Tamil Nadu), India

\section{P. Santhy} \\ Department of Soil Science \& Agricultural Chemistry, Tamil Nadu Agricultural University, \\ Coimbatore - 641003 (Tamil Nadu), India \\ M. Gnanachitra \\ Department of Agricultural Microbiology, Tamil Nadu Agricultural University, Coimbatore \\ - 641003 (Tamil Nadu), India \\ B. Gokila* \\ Department of Soil Science \& Agricultural Chemistry, Tamil Nadu Agricultural University, \\ Coimbatore - 641003 (Tamil Nadu), India \\ *Corresponding Author. Email: gokilasingh@gmail.com
}

\section{Article Info}

https://doi.org/10.31018/

jans.v13i4.3079

Received: September 29, 2021

Revised: November 12, 2021

Accepted: November 17, 2021

\section{How to Cite}

Kalaiselvi, K. et al. (2021). Effect of long term fertilization on phosphorus dynamics in root zone environment under finger millet - Maize cropping sequence. Journal of Applied and Natural Science, 13(4), 1383 - 1389. https://doi.org/10.31018/jans.v13i4.3079

\begin{abstract}
In an agro-ecosystem, phosphorus $(\mathrm{P})$ is found in organic and an inorganic form which includes soluble $\mathrm{P}$, sorbed $\mathrm{P}$ and mineral bounded $P$. In soil, added $P$ sources undergo various soil processes like mineralization, immobilization, precipitation, weathering, dissolution, sorption and desorption. For understanding the $\mathrm{P}$ dynamics in clay loam (Vertic Ustropept) soil, the present study was undertaken in $\mathrm{P}$ dynamics under rhizosphere and non-rhizosphere environment of maize in Long Term Fertilizer Experiment at Tamil Nadu Agricultural University, Coimbatore. The results revealed that the fractions of various pools of inorganic $\mathrm{NaOH}$ extractable $\mathrm{Fe}-\mathrm{P}, \mathrm{H}_{2} \mathrm{SO}_{4}$ extractable $\mathrm{Ca}-\mathrm{P}, \mathrm{NH}_{4} \mathrm{~F}$ extractable Al- $\mathrm{P}, \mathrm{NH}_{4} \mathrm{Cl}$ extractable Saloid $\mathrm{P}$ and $\mathrm{Na}$ citrate - Dithionate extractable Reductant soluble $\mathrm{P}$ were dominant in the non-rhizospheric soil than rhizospheric environment. The order of inorganic $P$ fractions in the non-rhizospheric and rhizospheric region of the soil was found as $\mathrm{Ca}-\mathrm{P}>\mathrm{Fe}-\mathrm{P}>\mathrm{Al}-\mathrm{P}>$ Reductant soluble-P $>$ Saloid $P$ and the knee-high stage of the non - rhizosphere soil recorded the highest inorganic as well organic $\mathrm{P}$ fractions. Irrespective of $\mathrm{P}$ fractions, $\mathrm{Ca}-\mathrm{P}$ was recorded high $\left(192.5 \& 186.7 \mathrm{mg} \mathrm{kg}^{-1}\right)$ followed by $\mathrm{Fe}-\mathrm{P}(40.8 \&$ $34.9 \mathrm{mg} \mathrm{kg}^{-1}$ ) at a knee-high stage in non-rhizosphere and rhizosphere, respectively. Practising various nutrient management systems, application of $100 \%$ recommended dose of fertilizer along with FYM @ $10 \mathrm{t} \mathrm{ha}^{-1}\left(\mathrm{~T}_{8}\right)$ recorded significant changes in all inorganic (Ca-P, Fe-P, Al-P, Reductant soluble-P, Saloid P), organic fractions and also Total $P$ followed by $150 \%$ NPK $\left(T_{3}\right)$ in sandy clay loam soil. Nowadays, increasing demand for $P$ fertilizer in India, judicious use of $P$ fertilizer is important. Despite that, intensively cultivated soils have a lot of $P$ reserves like organic and inorganic $P$ pools and effective way of $P$ transformation management could reduce the quantum of $P$ fertilization in soil.
\end{abstract}

Keywords: Inorganic P, Organic P, Phosphorus, Rhizosphere, Transformation

\section{INTRODUCTION}

Maize (Zea mays L.), known as 'Queen of cereals' is a high-production cereal crop of national importance in human food, animal feed, and industrial products, grown under varied agro-climatic conditions like arid and semi-arid tropics of India. In India, Tamil Nadu pro- duces rabi maize, contributing $40 \%$ of the total rabi production of the country (NCoMM,2017). Phosphorus $(\mathrm{P})$ is one such primary macro-nutrient available on the earth's crust as the eleventh most abundant element yet contributing only a small percentage for human utilization to meet out the food, fuel and fiber demands of the growing population (Cordell et al., 2008). 
Inorganic $P\left(P_{i}\right)$ and Organic $P\left(P_{0}\right)$ were the chemical forms existing in Soil $P$, which differs in their fate in different soils. Plant roots uptake as either $\mathrm{H}_{2} \mathrm{PO}_{4}{ }^{-}$or $\mathrm{HPO}_{4}{ }^{2-}$ anions (Shen et al., 2011). The quantity of available phosphate ions to plants largely depends on the soil $\mathrm{P}$ transformation according to $\mathrm{pH}$, fixation, retention of inorganic forms, mineralization of organic form, applied $P$ fertilizers, manures. Primary $P$ minerals, including apatites, strengite and variscite, are very stable, and the release of available $\mathrm{P}$ from these minerals by weathering is generally too slow to meet the crop demand through the direct application of phosphate rocks has proven relatively efficient for crop growth in acidic soils. In contrast, secondary P minerals, including calcium, iron and aluminum phosphates, vary in their dissolution rates, depending on size of mineral particles and soil $\mathrm{pH}$ (Oelkers and Valsami-Jones (2008). Organic phosphorus compounds occur as inositol phosphates, phosphonates, orthophosphate diesters, labile orthophosphate monoesters, organic polyphosphates, phospholipids and nucleic acids (Condron et al., 2005).

The rhizosphere is the critical narrow zone acting as a hotspot of interactions among plants, soils, and microorganisms that remain the most complex ecosystem on Earth (Hinsinger and Marschner, 2006). Some physiological activities are the key drivers of various rhizosphere processes in the modified rhizospheric environment by the plant roots (Shen et al., 2011). The mobilization and acquisition of soil nutrients and microbial dynamics, controlling nutrient use efficiency of crops is determined by the biogeochemical changes in the rhizosphere indirectly influencing crop productivity. The nature of low solubility and mobility in the soil makes $P$ to rapidly deplete in the rhizosphere by root uptake, resulting in a gradient shift of $P$ concentration in a radial direction away from the root surface (Purohit et al., 2020).

The unique properties of $P$ in soil, such as low solubility, low mobility, and two key processes dominantly control high fixation by the soil matrix, the $P$ availability to plants: 1) spatial availability and acquisition of $P$ and 2) bioavailability and acquisition of $P$ based on the rhizosphere chemical and biological processes. With this background, the present study was carried out to assess the effects of long term fertilization on the distribution of phosphorus and its different forms in the rhizosphere and non-rhizosphere soil under maize in Coimbatore Tamil Nadu.

\section{MATERIALS AND METHODS}

\section{Site description}

The present study was carried out to evaluate the $P$ transformation under long term fertilization and manuring with intensive cropping under finger millet-maize cropping sequence in the ongoing Long Term Fertilizer Experiment. This Long Term Fertilizer Experiment was started in 1972 by ICAR (All India Coordinated Research Project) and maintained by the Department of Soil Science and Agricultural Chemistry, Tamil Nadu Agricultural University, Coimbatore. The experimental site is located at $11^{\circ}$ North latitude, $77^{\circ}$ East longitude with an altitude of 426.7 meter above mean sea level in field no.36 F, Eastern block farm.

The experimental site belongs to the taxonomical classification of Inceptisol (Vertic Ustropept), with calcareous mixed black soil with sandy clay loam texture that comes under the Periyanaickenpalayam series. For examining the $\mathrm{P}$ dynamics, the present study comprised such as 50\% NPK $\left(\mathrm{T}_{1}\right), 100 \% \operatorname{NPK}\left(\mathrm{T}_{2}\right), 150 \%$ $\mathrm{NPK}\left(\mathrm{T}_{3}\right), 100 \% \mathrm{NPK}+$ Hand Weeding $\left(\mathrm{T}_{4}\right), 100 \% \mathrm{NPK}$ + Zinc $\left(T_{5}\right), 100 \% \mathrm{NP}\left(\mathrm{T}_{6}\right), 100 \% \mathrm{~N}\left(\mathrm{~T}_{7}\right), 100 \% \mathrm{NPK}+$ FYM $\left(T_{8}\right), 100 \%$ NPK (Sulphur free source) $\left(T_{9}\right)$ along with Control $\left(T_{10}\right)$ and replicated thrice in randomized block design. The test crop was maize (COHM 6) and being the continuous experiment, the crop number was $110^{\text {th }}$ under finger millet-maize cropping sequence. Initial soil Physico-chemical properties $\left(109^{\text {th }}\right.$ crop - postharvest soil) were analyzed and are furnished in Table 1.

\section{Soil sampling and analysis}

The representative soil samples were collected by excavating the soil along with the plant roots from $(20 \mathrm{~cm}$ diameter and $30 \mathrm{~cm}$ depth) cut. The rhizosphere soil was collected from the soil tightly adhering to the roots (Sun et al. 2020). The soil was shade dried and sieved under $2 \mathrm{~mm}$ sieve and used for analysis. Phosphorus fraction in the rhizosphere and non-rhizosphere soil was estimated by the methodology given by Petersen and Corey (1966), Mehta et al. (1954). All those parameters were analyzed in both the soils in knee-high, tasseling, milky, and harvest stage of the crop.

\section{Statistical analysis}

The data has been analyzed statistically using SPSS Statistics 23.0 with the appropriate variance techniques for Randomized Block Design (RBD). The means were compared by the least significant difference test $(C D<$ $5 \%$ ) and a heat map was generated for total $P$ using Python 3.8.

\section{RESULTS AND DISCUSSION}

\section{Inorganic phosphorus fractions (Pi) \\ Calcium - P ( $\mathrm{mg} \mathrm{kg}^{-1}$ )}

In soil, the $\mathrm{Ca}-\mathrm{P}$ fraction extracted by $0.5 \mathrm{~N} \mathrm{H}_{2} \mathrm{SO}_{4}$ were not easily available to the plants. $\mathrm{Ca}-\mathrm{P}$ was noticed as the predominant form of fraction than other forms of inorganic $P$ fractions and the same results were reported by Pant et al. (2018). The results re- 
Table 1. Initial properties of soil estimated during 2020 (post-harvest samples of $109^{\text {th }}$ crop)

\begin{tabular}{|c|c|c|c|}
\hline Soil properties & Value & Soil properties & Value \\
\hline Clay $(\%)$ & 32.6 & $\mathrm{NH}_{4} \mathrm{OAc} \mathrm{K}\left(\mathrm{kg} \mathrm{ha}^{-1}\right)$ & 530 \\
\hline Silt $(\%)$ & 11.8 & Exchangeable $\mathrm{Ca}\left(\mathrm{c} \mathrm{mol}\left(\mathrm{p}^{+}\right) \mathrm{kg}^{-1}\right)$ & 10.6 \\
\hline Fine sand (\%) & 15.1 & Exchangeable $\mathrm{Mg}\left(\mathrm{c}\right.$ mol $\left.\left(\mathrm{p}^{+}\right) \mathrm{kg}^{-1}\right)$ & 6.50 \\
\hline Coarse sand (\%) & 39.4 & Available $\mathrm{Zn}\left(\mathrm{mg} \mathrm{kg}^{-1}\right)$ & 0.62 \\
\hline $\mathrm{pH}$ & 8.5 & Available $\mathrm{Mn} \quad\left(\mathrm{mg} \mathrm{kg}^{-1}\right)$ & 1.34 \\
\hline$E C\left(d S m^{-1}\right)$ & 0.27 & Available $\mathrm{Cu}\left(\mathrm{mg} \mathrm{kg}^{-1}\right)$ & 1.24 \\
\hline $\operatorname{CEC}\left(\mathrm{c} \mathrm{mol}\left(\mathrm{p}^{+}\right) \mathrm{kg}^{-1}\right)$ & 25.2 & Available Fe (mg kg $\left.{ }^{-1}\right)$ & 2.92 \\
\hline Organic carbon $\left(\mathrm{g} \mathrm{kg}^{-1}\right)$ & 0.45 & Saloid $P\left(\mathrm{mg} \mathrm{kg}^{-1}\right)$ & 13.9 \\
\hline Total $\mathrm{P}\left(\mathrm{mg} \mathrm{kg}^{-1}\right)$ & 504 & Reductant soluble $\mathrm{P}\left(\mathrm{mg} \mathrm{kg}^{-1}\right)$ & 20.2 \\
\hline \multirow[t]{2}{*}{$\mathrm{KMnO}_{4} \mathrm{~N}\left(\mathrm{~kg} \mathrm{ha}^{-1}\right)$} & 280 & $\mathrm{Fe}-\mathrm{P}\left(\mathrm{mg} \mathrm{kg}^{-1}\right)$ & 23.5 \\
\hline & & $\mathrm{Al}-\mathrm{P}\left(\mathrm{mg} \mathrm{kg}^{-1}\right)$ & 23.3 \\
\hline \multirow[t]{2}{*}{ Olsen $\mathrm{P}\left(\mathrm{kg} \mathrm{ha}{ }^{-1}\right)$} & 22.8 & Ca-P $\left(\mathrm{mg} \mathrm{kg}^{-1}\right)$ & 126 \\
\hline & & Organic $\mathrm{P}\left(\mathrm{mg} \mathrm{kg}^{-1}\right)$ & 292 \\
\hline
\end{tabular}

vealed that the $\mathrm{Ca}-\mathrm{P}$ was found significantly high in the treatment $100 \%$ NPK + FYM @ 10 t ha $^{-1}$ (INM or $\mathrm{T}_{8}$ ) followed $150 \% \operatorname{NPK}\left(\mathrm{T}_{3}\right)$ under non-rhizospheric soil (bulk soil) than rhizospheric soil in all critical crop growth stages (Table 2). The highest $\mathrm{Ca}-\mathrm{P}$ of 192.5 and $186.7 \mathrm{mg} \mathrm{kg}^{-1}$ was recorded in $\mathrm{T}_{8}$ in knee-high maize under non - rhizospheric and rhizospheric soil, respectively and the lowest in absolute control $\left(\mathrm{T}_{10}\right)$. With the progress of crop growth stages, Ca-P was found to be low in both regions, which indicated that much more nutrients were taken by plant roots. Here, the soil belongs to calcareous instead; $P$ was retained as $\mathrm{Ca}-\mathrm{P}$ in soil irrespective of sources and doses of fertilizers and manures due to the more stabilized nature of the calcium system under high $\mathrm{pH}$. The labile nature of Ca- $\mathrm{P}$ was high in INM treatment in over all crop growth stages might be due to addition of manures along with chemical fertilizers and this results was inline with the findings of Yin and Liang (2013) and low amount of $\mathrm{Ca}-\mathrm{P}$ in the rhizosphere was due to the rapid uptake of $P$ by plant roots, which was facilitated by the organic exudation enhancing $P$ in the soil. Also, Wu et al. (2017) revealed that NPKM treated plots' application $\mathrm{P}$ fertilizer had a higher $\mathrm{Pi}$ fraction than $\mathrm{CK}$ (unfertilized control) and NK.

\section{Saloid $\mathbf{P}$ content $\left(\mathbf{m g ~ k g}^{-1}\right)$}

The loosely held $\mathrm{NH}_{4} \mathrm{Cl}$ extractable $(1 \mathrm{~N})$ fraction of $\mathrm{Pi}$, otherwise the so-called octa-calcium phosphate ions are reversible with exchange pools or fixed pools (Table 3). Increasing the graded levels of fertilizers led to an increase in the saloid $\mathrm{P}$ content in soil and it was found to low down when increasing the growth stages of maize crop. The significant changes were observed in the plot which received FYM @ 10t ha ${ }^{-1}$ with $100 \%$ NPK $\left(T_{8}\right)$ followed by $T_{3}$ in all the crop growth stages. This fraction also had higher content in the nonrhizosphere than the rhizospheric region because the

Table 2. Ca-P under rhizosphere $(R)$ and non-rhizosphere (NR) region at critical growth stages of maize

\begin{tabular}{lllllllll}
\hline \multirow{2}{*}{ Treatments } & \multicolumn{9}{c}{ Knee-High } & \multicolumn{3}{c}{ Tasseling } & \multicolumn{2}{c}{ Milky } & \multicolumn{3}{c}{ Harvest } \\
\cline { 2 - 8 } & \multicolumn{1}{c}{$\mathbf{R}$} & \multicolumn{1}{c}{$\mathbf{N R}$} & $\mathbf{R}$ & $\mathbf{N R}$ & $\mathbf{R}$ & $\mathbf{N R}$ & $\mathbf{R}$ & $\mathbf{N R}$ \\
\cline { 2 - 8 } $\mathrm{T}_{1}$ & 84.6 & 88.4 & 83.3 & 87.1 & 82.4 & 86.2 & 81.9 & 85.7 \\
$\mathrm{~T}_{2}$ & 144.9 & 148.6 & 142.8 & 146.5 & 141.9 & 145.6 & 141.4 & 145.1 \\
$\mathrm{~T}_{3}$ & 163 & 166.6 & 161.6 & 165.2 & 159.9 & 163.5 & 159.4 & 163 \\
$\mathrm{~T}_{4}$ & 144.4 & 147.6 & 142.4 & 145.6 & 142.1 & 145.3 & 141.6 & 144.8 \\
$\mathrm{~T}_{5}$ & 128 & 131.6 & 126.6 & 130.2 & 125.3 & 128.9 & 124.8 & 128.4 \\
$\mathrm{~T}_{6}$ & 144 & 147 & 141.2 & 144.2 & 140.8 & 143.8 & 140.3 & 143.3 \\
$\mathrm{~T}_{7}$ & 85.4 & 87.9 & 83.5 & 86 & 83.2 & 85.7 & 82.7 & 85.2 \\
$\mathrm{~T}_{8}$ & 186.7 & 192.5 & 184.4 & 190.2 & 183.2 & 189 & 182.7 & 188.5 \\
$\mathrm{~T}_{9}$ & 127.4 & 131.4 & 126.3 & 130.3 & 124.4 & 128.4 & 123.9 & 127.9 \\
$\mathrm{~T}_{10}$ & 61.9 & 64.2 & 60 & 62.3 & 59.1 & 61.4 & 58.6 & 60.9 \\
$\mathrm{SEd}$ & 6.55 & 6.74 & 6.46 & 6.65 & 6.41 & 6.6 & 6.38 & 6.57 \\
$\mathrm{CD}(0.05)$ & 13.75 & 14.15 & 13.57 & 13.97 & 13.46 & 13.86 & 13.41 & 13.8 \\
\hline
\end{tabular}

$T_{1}-50 \%$ NPK, $T_{2}-100 \%$ NPK, $T_{3}-150 \%$ NPK, $T_{4}-100 \%$ NPK + Hand Weeding, $T_{5}-100 \% N P K+Z$ Zinc, $T_{6}-100 \% N P, T_{7}-100 \% N, T_{8}$ $-100 \%$ NPK + FYM, $T_{9}-100 \%$ NPK (Sulphur free source) $\& T_{10}-$ Control 
applied $\mathrm{P}$ fertilizers got transformed into saloid $\mathrm{P}$, leading to the form of dicalcium phosphate. The highest Saloid $\mathrm{P}$ content of 28.6 and $19.6 \mathrm{mg} \mathrm{kg}^{-1}$ was recorded in $T_{8}$, followed by $150 \%$ NPK in non-rhizosphere soil. In $\mathrm{P}$ transformation, not all applied fertilizers directly available to the plants and part of $\mathrm{Pi}$ got adsorbed to the clay minerals and formed secondary minerals like AI-P, $\mathrm{Fe}-\mathrm{P}$ and $\mathrm{Ca}-\mathrm{P}$. Those fractions are available to the plants which applied $P$ would immobile in soil. This was supported by the findings of Mitran et al. (2016), who revealed that applying fertilisers and manures could increase the saloid bound $P$, but the magnitude of increase was found with $50 \%$ fertilizers and $50 \%$ manure as FYM.

\section{Reductant soluble $P$ content $\left(\mathrm{mg} \mathrm{kg}^{-1}\right)$}

In any fraction of primary or secondary minerals of $\mathrm{Pi}$ goes with a steady state with the magnitude with total $P$ with time. The less important inorganic $P$ fraction in soil is reductant soluble $P$, otherwise known as occluded $P$. This fraction was extracted using $0.3 \mathrm{M}$ sodium citrate and $\mathrm{Na}$ dithionate solution (Table 4). The highest reductant soluble $\mathrm{P}$ was noticed in treatment $\mathrm{T}_{8}$ of 34.5 $\mathrm{mg} \mathrm{kg}^{-1}$ in the non-rhizosphere soil of at knee high stage of maize crop and least value of $11.2 \mathrm{mg} \mathrm{kg}^{-1}$ were noticed in the rhizosphere unmanured control plot. Application of mineral fertilizers and manures led to increase the $\mathrm{P}$ fractions includes reductant soluble $\mathrm{P}$ or occluded $P$ and the same results were observed by

Table 3. Saloid $P$ under rhizosphere $(R)$ and non-rhizosphere (NR) region at critical growth stages of maize

\begin{tabular}{|c|c|c|c|c|c|c|c|c|}
\hline \multirow{3}{*}{ Treatments } & \multicolumn{8}{|c|}{ Saloid - P (mg kg $\left.{ }^{-1}\right)$} \\
\hline & \multicolumn{2}{|c|}{ Knee High } & \multicolumn{2}{|c|}{ Tasseling } & \multicolumn{2}{|c|}{ Milky } & \multicolumn{2}{|c|}{ Harvest } \\
\hline & $\mathbf{R}$ & NR & $\mathbf{R}$ & NR & $\mathbf{R}$ & NR & $\mathbf{R}$ & NR \\
\hline $\mathrm{T}_{1}$ & 11.7 & 15.6 & 10.4 & 14.3 & 9.5 & 13.4 & 9.0 & 12.9 \\
\hline $\mathrm{T}_{2}$ & 16.7 & 20.4 & 14.6 & 18.3 & 13.7 & 17.4 & 13.2 & 16.9 \\
\hline $\mathrm{T}_{3}$ & 19.6 & 23.2 & 18.2 & 21.8 & 16.5 & 20.1 & 16.0 & 19.6 \\
\hline $\mathrm{T}_{4}$ & 16.1 & 19.3 & 14.1 & 17.3 & 13.8 & 17.0 & 13.3 & 16.5 \\
\hline $\mathrm{T}_{5}$ & 13.2 & 16.8 & 11.8 & 15.4 & 10.5 & 14.1 & 10.0 & 13.6 \\
\hline $\mathrm{T}_{6}$ & 16.1 & 19.0 & 13.3 & 16.2 & 12.9 & 15.8 & 12.4 & 15.3 \\
\hline $\mathrm{T}_{7}$ & 11.9 & 14.3 & 10.0 & 12.4 & 9.7 & 12.1 & 9.2 & 11.6 \\
\hline $\mathrm{T}_{8}$ & 22.8 & 28.6 & 20.5 & 26.3 & 19.3 & 25.1 & 18.8 & 24.6 \\
\hline $\mathrm{T}_{9}$ & 13.4 & 17.4 & 12.3 & 16.3 & 10.4 & 14.4 & 9.9 & 13.9 \\
\hline $\mathrm{T}_{10}$ & 9.3 & 11.6 & 7.4 & 9.7 & 6.5 & 8.8 & 6.0 & 8.3 \\
\hline SEd & 0.78 & 0.97 & 0.69 & 0.89 & 0.64 & 0.83 & 0.62 & 0.81 \\
\hline $\mathrm{CD}(0.05)$ & 1.64 & 2.04 & 1.46 & 1.86 & 1.35 & 1.75 & 1.30 & 1.70 \\
\hline
\end{tabular}

$\mathrm{T}_{1}-50 \%$ NPK, $\mathrm{T}_{2}-100 \% \mathrm{NPK}, \mathrm{T}_{3}-150 \% \mathrm{NPK}, \mathrm{T}_{4}-100 \% \mathrm{NPK}+$ Hand Weeding, $\mathrm{T}_{5}-100 \% \mathrm{NPK}+$ Zinc, $\mathrm{T}_{6}-100 \% \mathrm{NP}, \mathrm{T}_{7}-100 \% \mathrm{~N}, \mathrm{~T}_{8}$ $-100 \%$ NPK + FYM, $T_{9}-100 \%$ NPK (Sulphur free source) $\& T_{10}-$ Control

Table 4. Reductant soluble-P under rhizosphere $(\mathrm{R})$ and non - rhizosphere (NR) region at critical growth stages of maize

\begin{tabular}{|c|c|c|c|c|c|c|c|c|}
\hline \multirow{3}{*}{ Treatments } & \multicolumn{8}{|c|}{ Reductant soluble-P (mg kg $\left.{ }^{-1}\right)$} \\
\hline & \multicolumn{2}{|c|}{ Knee High } & \multicolumn{2}{|c|}{ Tasseling } & \multicolumn{2}{|c|}{ Milky } & \multicolumn{2}{|c|}{ Harvest } \\
\hline & $\mathbf{R}$ & NR & $\mathbf{R}$ & NR & $\mathbf{R}$ & NR & $\mathbf{R}$ & NR \\
\hline $\mathrm{T}_{1}$ & 18.0 & 21.9 & 16.7 & 20.6 & 15.8 & 19.7 & 15.3 & 19.2 \\
\hline $\mathrm{T}_{2}$ & 22.6 & 26.3 & 20.5 & 24.2 & 19.6 & 23.3 & 19.1 & 22.8 \\
\hline $\mathrm{T}_{3}$ & 25.8 & 29.4 & 244 & 28.0 & 22.7 & 26.3 & 22.2 & 25.8 \\
\hline $\mathrm{T}_{4}$ & 22.7 & 25.9 & 20.7 & 23.9 & 20.4 & 23.6 & 19.9 & 23.1 \\
\hline $\mathrm{T}_{5}$ & 20.5 & 24.1 & 19.1 & 22.7 & 17.8 & 21.4 & 17.3 & 20.9 \\
\hline $\mathrm{T}_{6}$ & 22.1 & 25.1 & 19.3 & 22.3 & 18.9 & 21.9 & 18.4 & 21.4 \\
\hline $\mathrm{T}_{7}$ & 18.6 & 21.1 & 16.7 & 19.2 & 16.4 & 18.9 & 15.9 & 18.4 \\
\hline $\mathrm{T}_{8}$ & 28.7 & 34.5 & 26.4 & 32.2 & 25.2 & 31.0 & 24.7 & 30.5 \\
\hline $\mathrm{T}_{9}$ & 20.2 & 24.3 & 19.1 & 23.2 & 17.2 & 21.3 & 16.7 & 20.8 \\
\hline $\mathrm{T}_{10}$ & 14.5 & 16.7 & 12.6 & 14.8 & 11.7 & 13.9 & 11.2 & 13.4 \\
\hline SEd & 1.08 & 1.27 & 0.99 & 1.18 & 0.94 & 1.13 & 0.91 & 1.10 \\
\hline $\mathrm{CD}(0.05)$ & 2.27 & 2.67 & 2.09 & 2.49 & 1.97 & 2.37 & 1.92 & 2.32 \\
\hline
\end{tabular}

$T_{1}-50 \%$ NPK, $T_{2}-100 \%$ NPK, $T_{3}-150 \%$ NPK, $T_{4}-100 \%$ NPK + Hand Weeding, $T_{5}-100 \%$ NPK + Zinc, $T_{6}-100 \% N P, T_{7}-100 \% N, T_{8}$ $-100 \%$ NPK + FYM, $T_{9}-100 \%$ NPK (Sulphur free source) $\& T_{10}-$ Contr 
Kalaiselvi, K. et al. / J. Appl. \& Nat. Sci. 13(4), 1383 - 1389 (2021)

Table 5. Fe-P under rhizosphere $(R)$ and non- rhizosphere $(N R)$ region at critical growth stages of maize

\begin{tabular}{|c|c|c|c|c|c|c|c|c|}
\hline \multirow{3}{*}{ Treatments } & \multicolumn{8}{|c|}{ Fe-P $\left(\mathrm{mg} \mathrm{kg}^{-1}\right)$} \\
\hline & \multicolumn{2}{|c|}{ Knee High } & \multicolumn{2}{|c|}{ Tasseling } & \multicolumn{2}{|c|}{ Milky } & \multicolumn{2}{|c|}{ Harvest } \\
\hline & $\mathbf{R}$ & NR & $\mathbf{R}$ & NR & $\mathbf{R}$ & NR & $\mathbf{R}$ & NR \\
\hline $\mathrm{T}_{1}$ & 19.5 & 23.4 & 18.2 & 22.1 & 17.3 & 21.2 & 16.8 & 20.7 \\
\hline $\mathrm{T}_{2}$ & 26.3 & 30.0 & 24.2 & 27.9 & 23.3 & 27.0 & 22.8 & 26.5 \\
\hline $\mathrm{T}_{3}$ & 30.5 & 34.1 & 29.1 & 32.7 & 27.4 & 31.0 & 26.9 & 30.5 \\
\hline $\mathrm{T}_{4}$ & 26.4 & 29.6 & 24.4 & 27.6 & 24.1 & 27.3 & 23.6 & 26.8 \\
\hline $\mathrm{T}_{5}$ & 23.2 & 26.8 & 21.8 & 25.4 & 20.5 & 24.1 & 20.0 & 23.6 \\
\hline $\mathrm{T}_{6}$ & 26.2 & 29.2 & 23.4 & 26.4 & 23.0 & 26.0 & 22.5 & 25.5 \\
\hline $\mathrm{T}_{7}$ & 20.1 & 22.6 & 18.2 & 20.7 & 17.9 & 20.4 & 17.4 & 19.9 \\
\hline $\mathrm{T}_{8}$ & 34.9 & 40.8 & 32.6 & 38.5 & 31.4 & 37.3 & 30.9 & 36.8 \\
\hline $\mathrm{T}_{9}$ & 23.4 & 27.4 & 22.3 & 26.3 & 20.4 & 24.4 & 19.9 & 23.9 \\
\hline $\mathrm{T}_{10}$ & 16.7 & 18.9 & 14.8 & 17.0 & 13.9 & 16.1 & 13.4 & 15.6 \\
\hline SEd & 1.26 & 1.45 & 1.17 & 1.36 & 1.12 & 1.31 & 1.10 & 1.29 \\
\hline $\mathrm{CD}(0.05)$ & 2.65 & 3.05 & 2.47 & 2.87 & 2.35 & 2.75 & 2.30 & 2.70 \\
\hline
\end{tabular}

$T_{1}-50 \%$ NPK, $T_{2}-100 \%$ NPK, $T_{3}-150 \%$ NPK, $T_{4}-100 \%$ NPK + Hand Weeding, $T_{5}-100 \% N P K+Z$ inc, $T_{6}-100 \% N P, T_{7}-100 \% N, T_{8}$ $-100 \%$ NPK + FYM, $T_{9}-100 \%$ NPK (Sulphur free source) \& $T_{10}-$ Control.

Anjali and Dhananjya (2017) who observed the addition of $\mathrm{P}$ fertilizers significantly increases the fixation and transformation in the soil so that, the solubility leads to decreased. And also, Mitran et al. (2016) revealed that application of FYM and inorganic fertilization got higher reductant $P$ than other treatments.

\section{Fe-P content ( $\left.\mathrm{mg} \mathrm{kg}^{-1}\right)$}

The part of phosphorus has bounds with soil Fe oxide and $0.1 \mathrm{~N} \mathrm{NaOH}$ extracted it also. When the equilibrium gets disturbed, it may be slightly available to the plants because it is an active part of $P$ in soil. The highest $\mathrm{Fe}-\mathrm{P}$ of 40.8 and 34.9 was recorded by $\mathrm{T}_{8}$ treat- ment in knee-high stages of non-rhizosphere and rhizosphere soil, respectively (Table 5.). Application of FYM along with chemical fertilizers would lead to supply the nutrients and reducing the leaching of $P$ and it gets bound with native $\mathrm{Fe}$ by chemisorption or clayorganometal complexes.). The relative abundance of this fraction was high next to Ca-P, which dominated all the inorganic fractions of $P$ and was due to the calcareousness nature of the soil. This was supported by the findings of Soremi et al. (2017) who stated that applied $P$ could be mineralized and converted in to Fe-P, Ca-P and out of three active inorganic $P$ fractions such as $\mathrm{Fe}$ $-\mathrm{P}, \mathrm{Ca}-\mathrm{P}$ and Al-P the Fe-P was observed higher by

Table 6. Al-P under rhizosphere $(\mathrm{R})$ and non- rhizosphere $(N R)$ region at critical growth stages of maize

\begin{tabular}{|c|c|c|c|c|c|c|c|c|}
\hline \multirow{3}{*}{ Treatments } & \multicolumn{8}{|c|}{ Al-P (mg kg $\left.{ }^{-1}\right)$} \\
\hline & \multicolumn{2}{|c|}{ Knee High } & \multicolumn{2}{|c|}{ Tasseling } & \multicolumn{2}{|c|}{ Milky } & \multicolumn{2}{|c|}{ Harvest } \\
\hline & $\mathbf{R}$ & NR & $\mathbf{R}$ & NR & $\mathbf{R}$ & NR & $\mathbf{R}$ & NR \\
\hline$\overline{T_{1}}$ & 20.7 & 24.5 & 19.4 & 23.2 & 18.5 & 22.3 & 18.0 & 21.8 \\
\hline $\mathrm{T}_{2}$ & 25.4 & 29.1 & 23.3 & 27.0 & 22.4 & 26.1 & 21.9 & 25.6 \\
\hline $\mathrm{T}_{3}$ & 30.4 & 34.0 & 29.0 & 32.6 & 27.3 & 30.9 & 26.8 & 30.4 \\
\hline $\mathrm{T}_{4}$ & 25.3 & 28.5 & 23.3 & 26.5 & 23.0 & 26.2 & 22.5 & 25.7 \\
\hline $\mathrm{T}_{5}$ & 23.8 & 27.4 & 22.4 & 26.0 & 21.1 & 24.7 & 20.6 & 24.2 \\
\hline $\mathrm{T}_{6}$ & 25.9 & 28.9 & 23.1 & 26.1 & 22.7 & 25.7 & 22.2 & 25.2 \\
\hline $\mathrm{T}_{7}$ & 20.4 & 22.9 & 18.5 & 21.0 & 18.2 & 20.7 & 17.7 & 20.2 \\
\hline $\mathrm{T}_{8}$ & 33.4 & 39.3 & 31.1 & 37.0 & 29.9 & 35.8 & 29.4 & 35.3 \\
\hline $\mathrm{T}_{9}$ & 23.5 & 27.5 & 22.4 & 26.4 & 20.5 & 24.5 & 20.0 & 24.0 \\
\hline$T_{10}$ & 15.4 & 17.6 & 13.5 & 15.7 & 12.6 & 14.8 & 12.1 & 14.3 \\
\hline SEd & 1.24 & 1.43 & 1.16 & 1.35 & 1.10 & 1.29 & 1.08 & 1.27 \\
\hline $\mathrm{CD}(0.05)$ & 2.61 & 3.01 & 2.43 & 2.83 & 2.31 & 2.71 & 2.26 & 2.66 \\
\hline
\end{tabular}

$T_{1}-50 \%$ NPK, $T_{2}-100 \%$ NPK, $T_{3}-150 \%$ NPK, $T_{4}-100 \%$ NPK + Hand Weeding, $T_{5}-100 \% N P K+$ Zinc, $T_{6}-100 \% N P, T_{7}-100 \% N, T_{8}$ $-100 \%$ NPK + FYM, $T_{9}-100 \%$ NPK (Sulphur free source) \& $T_{10}-$ Control. 
using manures.

\section{Al-P content ( $\mathrm{mg} \mathrm{kg}^{-1}$ )}

Similarly, the Ca-P and Fe-P, Al bound Phosphorus is also one of the major $\mathrm{Pi}$ fractions in soil $\mathrm{P}$ transformation (Table 6). When compared to the nutrient management practices, INM or FYM @ $10 \mathrm{t} \mathrm{ha}^{-1}$ along with $100 \%$ NPK showed the highest Al-P of 39.3, 37.0, 35.8 $\& 35.3 \mathrm{mg} \mathrm{kg}^{-1}$ in knee-high, tasseling, milky and harvest stages of maize, respectively in non-rhizosphere soil. Due to the calcareous nature, the unutilised part of the applied $\mathrm{P}$ fertilizers gone to bounds with native $\mathrm{Ca}, \mathrm{Fe}$ and $\mathrm{Al}$ ions. And the rhizosphere region, the root exudates and other organic acids would interfere with the soil $\mathrm{pH}$ and make the ions dissolute in to the solution phase and easily exchange with root hair $\mathrm{H}^{+}$ions and others. Therefore the bulk soil had high Al- $\mathrm{P}$ than root zone of the plants. However, any fraction attains changes while the solid-liquid equilibrium gets disturbed by applying fertilizers, crop uptake, leaching etc. This was in line with the findings of Anjali and Dhananjya (2017) who stated that application of DAP would favoured the formation and accumulation of Al-P in soil.

\section{Total P $\left(\mathbf{m g ~ k g}^{-1}\right)$}

Total $\mathrm{P}$ as it includes $\mathrm{Po}$ and $\mathrm{Pi}$ and each fraction has reversible with both forms of $P$ in soil and the result was represented in a heat map (Fig 1.). The total $P$ was found significantly high in the non-rhizospheric soil at high knee stage in $100 \%$ NPK + FYM @ $10 \mathrm{t} \mathrm{ha}^{-1}\left(\mathrm{~T}_{8}\right)$ treatment $\left(814 \mathrm{mg} \mathrm{kg}^{-1}\right)$ which has depicted in the dark blue colour of scale 200 and the lowest (233 $\mathrm{mg} \mathrm{kg}^{-1}$ ) observed in the rhizospheric soil at harvest stage in control plot which has depicted in light red between 600 to 800 scale. The total $P$ content in soil usually exceeds the plant needs and their low mobility of soil $P$ restricts its availability to plants reported by Shen et al. (2011).

\section{Organic phosphorus fractions (Po) $\left(\mathrm{mg} \mathrm{kg}^{-1}\right)$}

Soil $P$ dynamics, organic fraction of $P$ has a dominant part in total $P$. It includes phosphate esters of nucleic acids, phospholipids, sugar phosphates and inositol phosphate, also derived from microbial synthesis rather than accumulation of plant and animal residues. Here, $\mathrm{T}_{8}$ treatments received high $\mathrm{Po}\left(478 \mathrm{mg} \mathrm{kg}^{-1}\right)$ than chemically fertilized plot and absolute control (145 mg $\mathrm{kg}^{-1}$ - knee-high stage) in bulk soil and rhizospheric region (low at harvest stage) in maize crop (Fig. 2 and 3). This might be due to the added organic amendments because organic $C$ and organic bounded $P$ were directly related. In $P$ mineralization, the organic $C$ get mineralized and $\mathrm{C}$ : $\mathrm{P}_{\mathrm{o}}$ ratio might have declined and steadystate of supply of $P$ to the labile pool. A similar finding was reported by Qian and Schoenau (2000), who re-

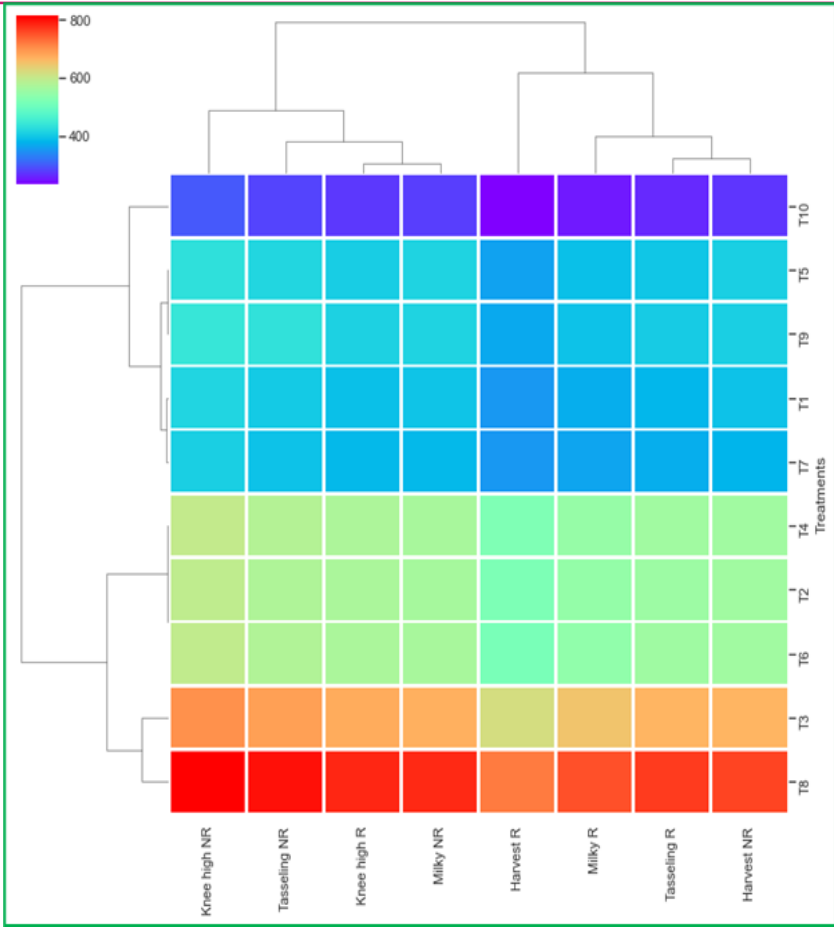

Fig. 1. Total $P$ content $\left(m g \mathrm{~kg}^{-1}\right)$ in various crop growth stages of maize

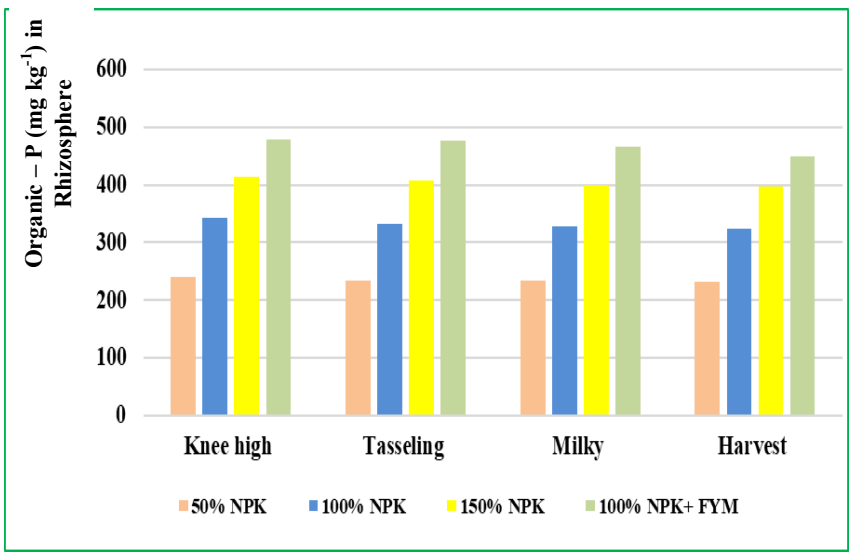

Fig. 2. Organic $P$ under rhizosphere $(R)$ region at critical growth stages of maize

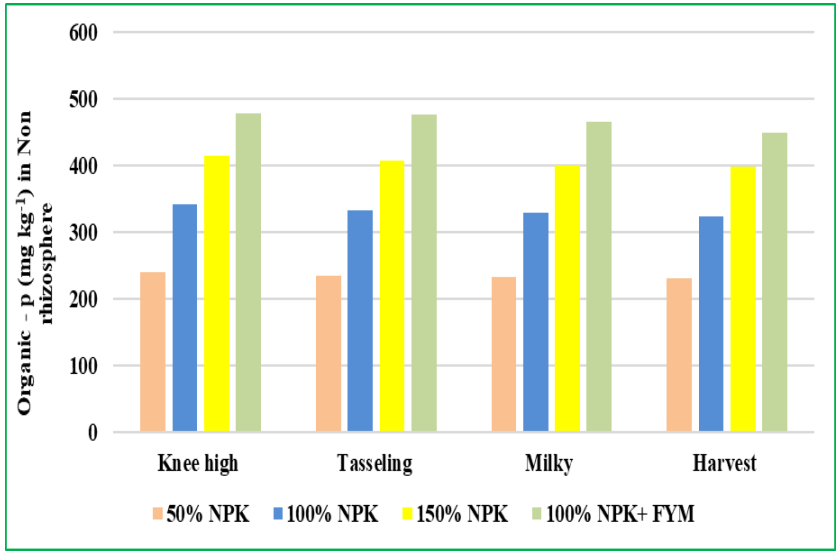

Fig. 3. Organic $P$ under Non- rhizosphere $(R)$ region at critical growth stages of maize 
ported that labile Po arises remarkably due to the continuous addition of organic manures.

\section{Conclusion}

$P$ transformation in soil depends on spatial and temporal changes during soil development in the bio- geocycle. The present study brought the importance of the chemistry of $\mathrm{P}$ in solid-liquid alteration under the root zone environment of the crop. Bulk soil had high $\mathrm{Pi}$ fractions (Saloid - P, Reductant Soluble - P, Fe-P, Ca$\mathrm{P}, \mathrm{Al}-\mathrm{P}$ ) than rhizosphere regions and these may be the chemical conditions and biological activity within the rhizosphere that causes a depletion of the concentration of orthophosphate in the soil, as well as from organic and inorganic forms of extractable $P$. Both the region, application FYM @ $10 \mathrm{t} \mathrm{ha}^{-1}$ with $100 \%$ NPK showed highest $\mathrm{Po}$ as well $\mathrm{Pi}$ fraction in soil. $\mathrm{P}$ being a non-renewable resource, rhizosphere based nutrient management strategies are suggested to be framed for improving phosphorus use efficiency and breeding more crop cultivars or genotypes for high $\mathrm{P}$ acquisition.

\section{Conflict of interest}

The authors declare that they have no conflict of interest.

\section{REFERENCES}

1. Anjali, M. C. \& Dhananjaya, B. C. (2017). Influence of different levels of phosphorus and PSB seed treatment on $P$ fraction in soil at different growth stages of groundnut (Arachis hypogaea L.). International Journal of Current Microbiology and Applied Sciences., 6(10), 216-224. https://doi.org/10.20546/ijcmas.2017.610.027

2. Condron L.M., Turner B.L. \& Cade-Menun. (2005). Chemistry and dynamics of soil organic phosphorus. In JT Sims, AN Sharpley (eds). Phosphorus: Agriculture and the Environment. American Society of Agronomy, Crop Science Society of America, Soil Science Society of America, Inc., Madison, WI, pp 87-121. https://doi.org/10.2134/agron vmonogr46.c4.

3. Cordell, D. (2008). The story of phosphorus: missing global governance of a critical resource. SENSE Earth Systems Governance, Amsterdam. http://www.glogov.de/im ages/doc/Cordell. pdf.

4. Hinsinger, P. \& P. Marschner. (2006). Rhizosphere - perspectives and challenges - a tribute to Lorenz Hiltner 1217 September 2004 - Munich, Germany. Plant and Soil, 283 (1), vii-viii. 10.1007/s11104-008-9774-2.

5. Mehta, N., Legg, J., Goring, C. \& Black, C. (1954). Deter- mination of organic phosphorus in soils: I. Extraction method. Soil Science Society of America Journal, 18 (4),443-449. https://doi.org/10.2136/sssaj1954.0361599 5001800040023x.

6. Mitran, T., Mani, P. K., Basak, N., Mazumder, D. \& Roy, M. (2016). Long-term manuring and fertilization influence soil inorganic phosphorus transformation vis-a-vis rice yield in a rice-wheat cropping system. Archives of Agronomy and Soil Science, 62(1),1-18. https://doi.org/10.10 80/03650340.2015.1036747.

7. NCoMM.(2017). Maize. NCoMM Special report. https:// www.ncml.com/Upload/New/Pdf/c7495fab-54d7-4b03a04a-47c2da337039.pdf.

8. Oelkers, E.H. \& Valsami-Jones, E. (2008). Phosphate mineral reactivity and global sustainability. Elements, 4, 83-87. https://doi.org/10.2113/GSELEMENTS.4.2.83.

9. Petersen, G. \& Corey, R. (1966). A modified Chang and Jackson procedure for routine fractionation of inorganic soil phosphates. Soil Science Society of America Journal, 30(5), 563-565. https://doi.org/10.2136/sssaj1966.036159 95003000050012x.

10. Purohit, D., Mandal, M., Dash, A., Rout, K. K. \& Panda, N. (2020). Impact of long term fertilization on soil phosphorous availability in the rhizosphere of rice grown in acid inceptisols. Journal of the Indian Society of Coastal Agricultural Research, 38(1):19-26.

11. Qian, P. \& Schoenau, J. (2000). Fractionation of $P$ in soil as influenced by a single addition of liquid swine manure. Canadian J. of Soil Sci., 80(4),561-566. https://doi.or g/1 0.4141/S00-020.

12. Shen, J., Yuan, L., Zhang, J., Li, H., Bai, Z., Chen, X., Zhang, W. \& Zhang, F. (2011). Phosphorus dynamics: from soil to plant. Plant Physiology,156(3),997-1005. https://doi.org/10.1104/pp.111.175232.

13. Soremi, A., Adetunji, M., Azeez, J., Adejuyigbe, C. \& Bodunde, J. (2017). Speciation and dynamics of phosphorus in some organically amended soils of southwestern Nigeria. Chemical Speciation and Bioavailability, 29(1): 42-53. https://doi.org/10.1080/09542299.2017.1287549

14. Sun, B., Gao, Y., Wu, X., Ma, H., Zheng, C., Wang, X., Zhang, H., Li, Z. \& Yang, H. (2020). The relative contributions of $\mathrm{pH}$, organic anions, and phosphatase to rhizosphere soil phosphorus mobilization and crop phosphorus uptake in maize/alfalfa polyculture. Plant and Soil. 447. DOI. 10.1007/s11104-019-04110-0.

15. Wu, Q., Zhang, S., Zhu, P., Huang, S., Wang, B., Zhao, L. $\& \mathrm{Xu}$, M. (2017). Characterizing differences in the phosphorus activation coefficient of three typical cropland soils and the influencing factors under long-term fertilization. PLoS One, 12(5),e0176437. https://doi.org/10.1371/ journal.pone. 0176437.

16. Yin, Y. \& Liang, C. (2013). Transformation of phosphorus fractions in paddy soil amended with pig manure. Journal of Soil Science and Plant Nutrition.13(4),809-818. http:// dx.doi.org/10.4067/S0718-95162013005000064. 